\title{
SEDIMENT BUDGET FORMULATION VIA EXHAUSTIVE SEARCH METHOD
}

\author{
Jason A. Engle, P.E. ${ }^{1}$, Kelly R. Legault, Ph.D., P.E. ${ }^{1}$ and Julie D. Rosati, Ph.D., P.E. ${ }^{2}$
}

\begin{abstract}
A regional sediment budget for St. Augustine Inlet and St. Johns County, Florida, was developed for the 1999 to 2010 period. Development of the sediment budget had three main objectives: characterize the transport pathways and magnitudes for the 1999 to 2010 period, compare to an earlier sediment budget for 1974 to 1995 (Srinivas and Taylor 1998), and provide input to numerical modeling of the region (Reports 2 and 3, Beck and Legault 2012a,b). An innovative method was developed to create an inlet sediment budget using high quality measured volume changes for an inlet and beach system. Methods described in the Coastal Engineering Manual (CEM-V-6 2008) and Bodge (1999) were applied to determine the extent of inlet influence along the adjacent beaches, the total inlet sink, and a regional sediment budget for a given set of measured volume changes occurring at St. Augustine Inlet in northeast Florida, U.S.A.
\end{abstract}

Keywords: tidal inlet, sediment budget; optimization

\section{INTRODUCTION}

St. Johns County encompasses a $24-\mathrm{km}$ beach and inlet system located in northeast Florida on the Atlantic coastline of the United States (Fig. 1). Historical management practices at St. Augustine Inlet and adjacent beaches have involved maintaining the navigation channel and placing dredged material either offshore or onto adjacent beaches in moderate quantities ( 200-500K cu yd) since the 1970's. In 1998, an Inlet Management Plan (IMP) was developed (Taylor Engineering 1998) to guide sediment management practices at the Inlet. The 1998 IMP recommended that sediment be dredged from the inlet and placed on the eroded beaches of St. Augustine Beach, south of the inlet. First in 2001 and then again in 2005, the St. Johns County Federal Shore Protection Project (SPP) removed sand from the inlet outer channel and ebb shoal and placed it on St. Augustine Beach. A total of 7 million cubic yards was placed. This large-scale dredging of the inlet was controversial, with some residents north of the inlet claiming that the dredging of the ebb shoal had exacerbated erosion on the north beaches. A study was initiated by U.S. Army Corps of Engineers Jacksonville District and the Coastal Hydraulics Laboratory to investigate the erosion and accretion patterns and sediment transport processes at St. Augustine Inlet and the adjacent beaches. This report summarizes one portion of that work.

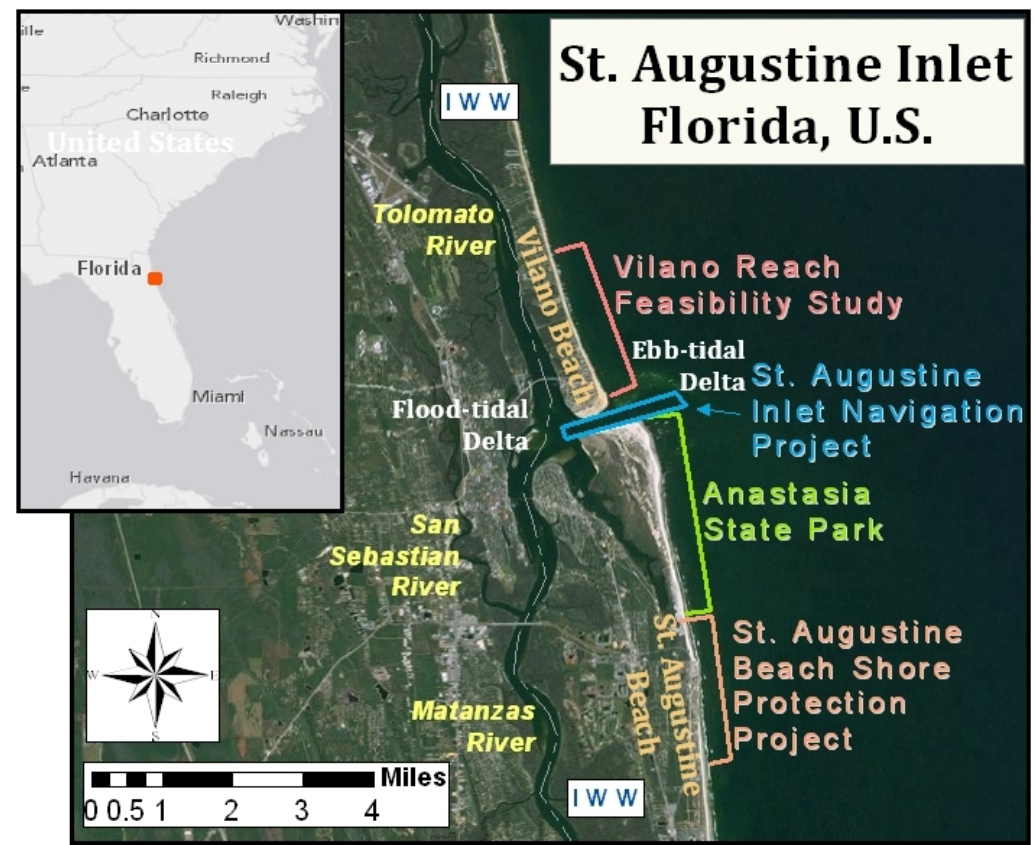

Figure 1. Study area location map for St. Johns County, Florida, and the U.S. Army Corps of Engineers' projects in the region.

\footnotetext{
${ }^{1}$ Jacksonville District, U.S. Army Corps of Engineers, 701 San Marco Boulevard, Jacksonville, Florida, 32207 U.S.A. ${ }^{2}$ Coastal and Hydraulics Laboratory, U.S. Army Corps of Engineers, 3909 Halls Ferry Road, Vicksburg, Mississippi, 39180 U.S.A 
The State of Florida is developing an updated IMP for St. Augustine Inlet based in part on these new analyses. Fundamental to the development of a new IMP is the quantification of beach and inlet volume change and to further understand the natural sediment transport regime and the influence of dredge and fill activities that occur at the inlet on adjacent beaches. Both a central and essential component of the new IMP was an updated Sediment Budget.

A comprehensive analysis of available bathymetric and topographic data was performed by the U.S. Army Engineer District, Jacksonville (hereafter, the Jacksonville District), and the Coastal Inlets Research Program (CIRP) at the Coastal and Hydraulics Laboratory (CHL), and are documented in three technical reports (Legault et al. 2012; Beck and Legault 2012a; Beck and Legault 2012b). These data were formulated into a present-day sediment budget in order to clearly define regional sediment dynamics for the purpose of subsequent regional sediment modeling and long-term planning of the sediment resources and shore protection needs for the county.

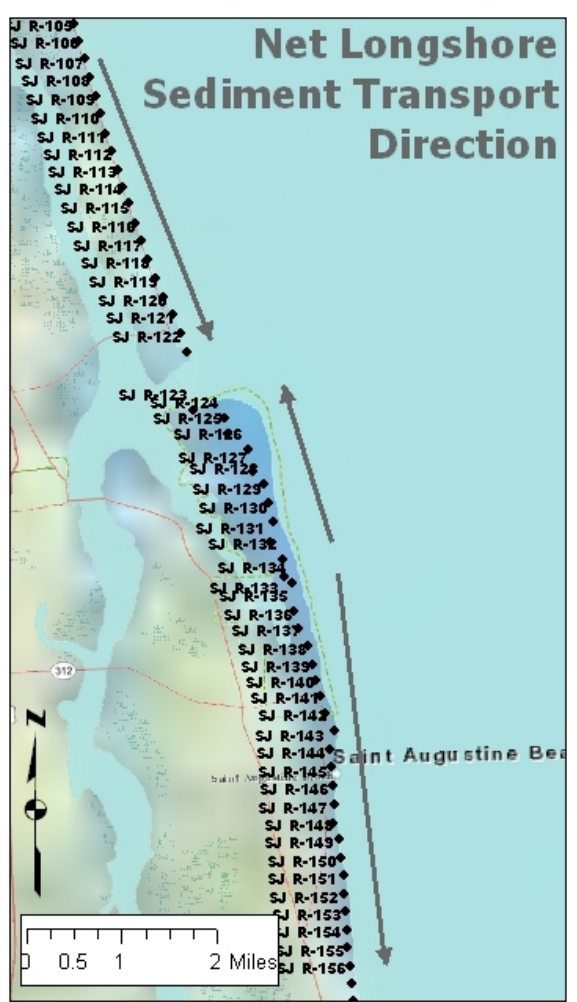

Figure 2. General net longshore sediment transport directions in the vicinity of the inlet.

\section{Study Area}

Sediments within the nearshore along northern St. Johns County are typically quartz sand with varying fractions of carbonate shell hash. The net direction of regional sand transport (Fig. 2) and general trends in volumetric change are described extensively by Legault et al. (2012).

Dredging and beach nourishment activities in the earlyto mid-2000s were conducted using the navigation channel and ebb-tidal delta as a sediment source. Table 1 lists ebbtidal delta volumes and Table 1 lists the volume of sediment removed from the inlet channel and its ebb-tidal delta from 1986 to 2010. Nearly 7 million cubic yards of sediment were removed from the inlet system between 1999 and 2007, and a slow recovery of sediment is reflected in the volumetric change of the ebb-tidal delta in Table 2 in 2010.

\begin{tabular}{|c|c|c|c|c|}
\hline Date & $\begin{array}{l}\text { Volume } \\
\text { Dredged } \\
\text { (cy) }\end{array}$ & $\begin{array}{l}\text { Nearshore } \\
\text { Placement } \\
\text { (cy) }\end{array}$ & $\begin{array}{l}\text { Beach Fill } \\
\text { (cy) }\end{array}$ & $\begin{array}{l}\text { Placement } \\
\text { Length } \\
\text { (mi.) }\end{array}$ \\
\hline 1986 & 121,247 & 121,247 & - & 2.6 \\
\hline 1996 & 257,649 & - & 257,649 & 2.6 \\
\hline 1997 & 130,000 & - & 130,000 & 2.6 \\
\hline 1998 & 130,000 & - & 130,000 & 2.6 \\
\hline 2001 & $2,200,000$ & - & $2,200,000$ & 1.1 \\
\hline 2002-03 & $2,000,000$ & - & $2,000,000$ & 3.6 \\
\hline 2005 & $2,800,000$ & - & $2,800,000$ & 2.6 \\
\hline
\end{tabular}

\begin{tabular}{|l|l|}
\hline \multicolumn{2}{|l|}{$\begin{array}{l}\text { Table 2. Measured ebb-delta volume of } \\
\text { St. Augustine Inlet, Florida at the 30ft } \\
\text { contour (Legault et al. 2012). }\end{array}$} \\
\hline Date & Volume (million cy) \\
\hline 1986 & 30.4 \\
1998 & 35.5 \\
1999 & 35.9 \\
2007 & 29.5 \\
2010 & 30.9 \\
\hline
\end{tabular}

\section{Measured Volume Change}

Beach profile surveys were analyzed for volume change for the time period from 1999 - 2010, details of which can be found in Legault et al. 2012. Average annual volume changes per 5000 linear alongshore feet were examined for the time period from 1986 to 1999, (prior to ebb shoal mining) and for 1999 to 2007 and 1999 to 2010 (prior to large-scale inlet dredging) (Fig. 3). The rate of beach profile volume change north of the inlet was similar for all three time periods, except a rather stable region between R-46 and R-67 over the 1999 to 2007 time period. South of the inlet, the beach was accretional over all time periods from R-123 to R-125, was accretional between R-129 and R-131 and was generally erosive to $\mathrm{R}-151$. The St. Augustine Beach Pier located at R-142 is within the highly erosional area between R138 and R-146. Change in volume and the volumetric rate of change of the ebb shoal are shown in Table 3. 


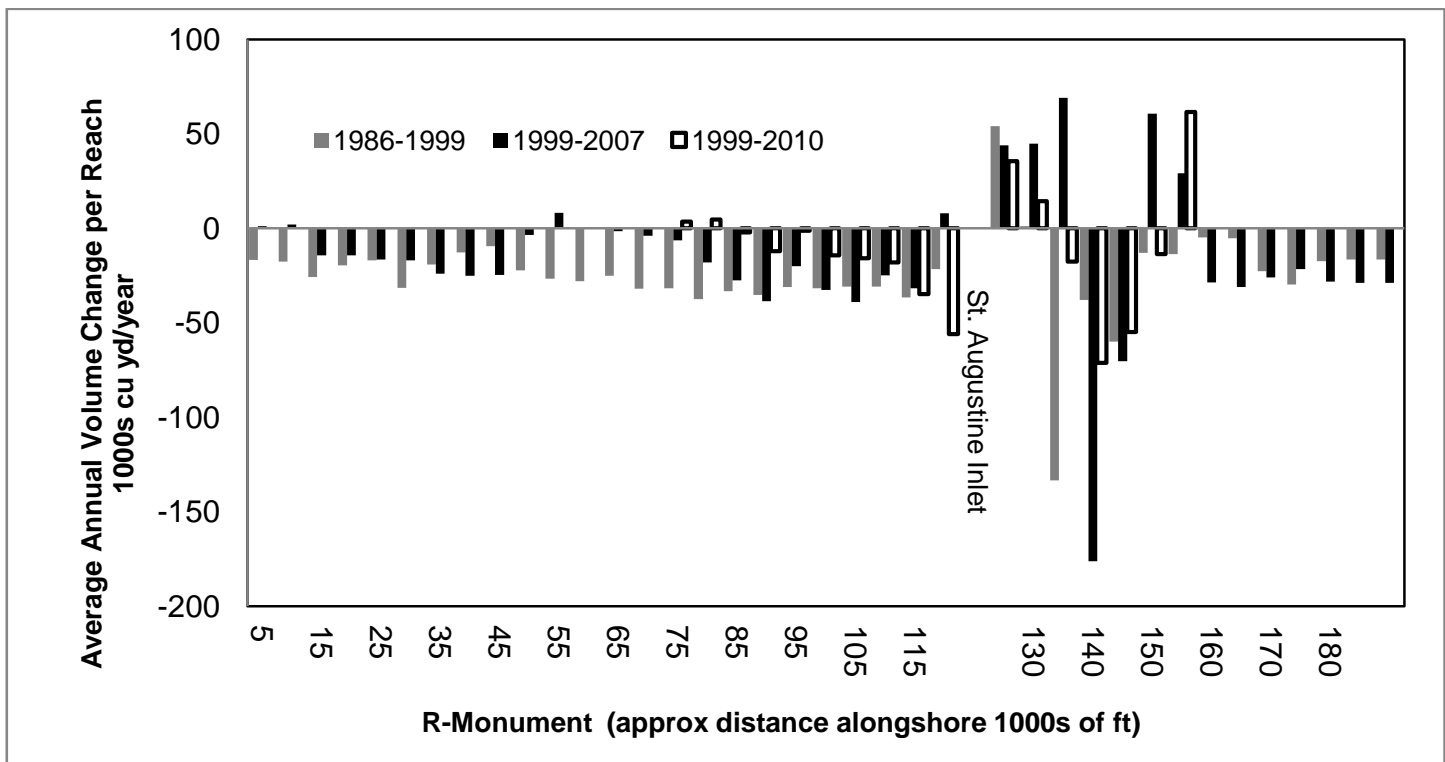

Figure 3. Average annual reach volume change 1986 to 1999, 1999 to 2007 (fill removed), and 1999 to 2010 (fill removed). Reaches are approximately $5000 \mathrm{ft}$ in the alongshore.

\section{Inlet Sink}

In most cases, natural and stabilized inlets remove sand from the littoral system through shoaling in channels and accretion of ebb- and flood-tidal shoals. To assess the volumetric impact of inlet shoaling upon the adjacent shorelines, a combination of analyses is typically necessary. In this case, we examined historical volumetric changes over the region of interest, and calculated the inlet's net sink effect. The inlet's sink effect first assesses the littoral impact within the inlet, and determines the relative volumetric contribution from adjacent shoreline along which the inlet's impact is manifest. The net inlet sink for St. Augustine Inlet is 278,000 cu yd/year balanced by approximately 99,000 cu $\mathrm{yd} / \mathrm{yr}$ of erosion from beaches to the north and 179,000 $\mathrm{cu} \mathrm{yd/yr}$ of erosion from beaches south (Table 4).

\section{Table 3. Change in Ebb Shoal Volume}

\begin{tabular}{|lcc|}
\hline Interval & $\Delta V$ Ebb Shoal, cu yd & $\Delta V$ cu yd/yr \\
\hline $1986-1998$ & $5,071,250$ & 390,096 \\
$1998-2003$ & $1,065,849$ & 266,462 \\
$2003-2007$ & 866,938 & 216,735 \\
$1998-2007$ & $1,932,787$ & 241,598 \\
$1998-2009$ & $2,733,274$ & 248,480 \\
\hline
\end{tabular}

\begin{tabular}{|lllllll|}
\hline \multicolumn{3}{|c|}{ Table 4. Inlet sink analysis for $1999-2010$} & & \\
\hline $\begin{array}{l}\text { Volumetric } \\
\text { Rate } \\
\text { (cu yd/yr) }\end{array}$ & $\begin{array}{l}\text { Borrow } \\
\text { (cu yd/yr) }\end{array}$ & $\begin{array}{l}\text { Flood Tidal } \\
\text { Shoals and } \\
\text { Channels } \\
\text { (cu yd/yr) }\end{array}$ & $\begin{array}{l}\text { Inlet Sink } \\
\text { (cu yd/yr) }\end{array}$ & $\begin{array}{l}\text { Adjacent Beaches (cu } \\
\text { yd/yr) }\end{array}$ & $\begin{array}{l}\text { Imbalance } \\
\text { (cu yd/yr) }\end{array}$ \\
\hline$-385,000$ & 635,000 & 29,000 & 278,000 & $-99,000$ & $-179,000$ & 0 \\
\hline
\end{tabular}




\section{SEDIMENT BUDGET METHODOLOGY}

For development of the 1999 to 2010 sediment budget, the Bodge Method (Bodge 1999; Bodge and Rosati 2003) was applied. This innovative application of the Bodge Method uses the volumetric change rates derived from the inlet sink analysis (Table 4) previously described, and evaluates these against a range of feasible net and gross transport rates for the region. The method also assigns a likely

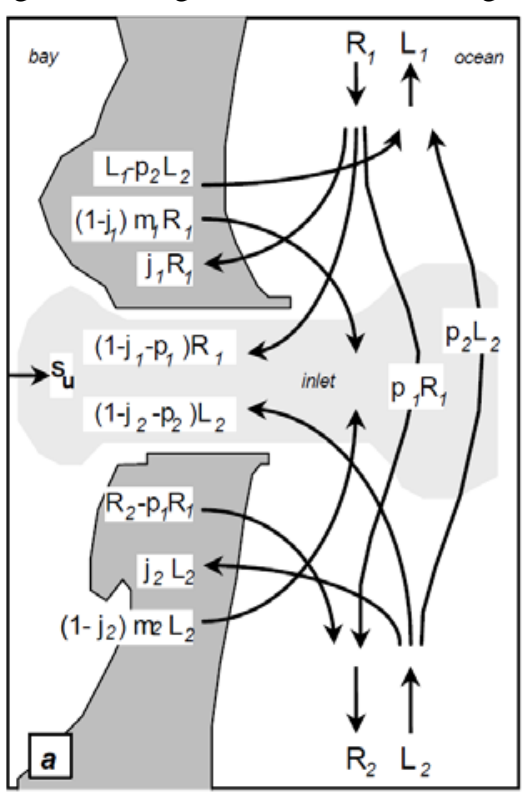

Figure 4. Definition of variables for sediment budget (from Bodge and Rosati 2003). range in values for bypassing, inlet-induced erosion, and impoundment at jetties (if any) for both updrift and downdrift beaches. The resulting calculations that balance the known volumetric change rates comprise a "Family of Solutions" of which each individual "member" (one resultant calculation) represents a viable, balanced budget. A subset from the Family of Solutions may be extracted based upon known information and a more thorough understanding of the region to better represent the most likely sediment budget during the period of interest.

Figure 4 illustrates the Bodge Method. The system of equations developed for the sediment budget applied values for left and right beaches from the perspective of a seawardlooking observer. The variables are defined as follows: $p_{1}, p_{2}$ are the fraction of incident transport $(R$ or $L)$ naturally bypassed across the inlet ( $p_{1}=$ from the left, $p_{2}=$ from the right; $0.0=$ no bypassing; $1.0=$ perfect bypassing); $m_{1}$ is the local inlet-induced transport from the left shoreline into the inlet (expressed as a fraction or multiple of the right-directed incident transport, $R_{1}$ ); $m_{2}$ is the local inlet-induced transport from the right shoreline into the inlet (expressed as a fraction or multiple of the left-directed incident transport, $L_{2}$ ). The parameters $j_{1}$ and $j_{2}$ are the trapping efficiency of jetties, which can range from 0 (no trapping) to 1 (perfect trapping). $\mathrm{S}_{\mathrm{U}}$ is the volume of sand shoaling the inlet from sources landward of the inlet.

To develop the Family of Solutions, the parameters $p_{1}, p_{2}, m_{1}$, and $m_{2}$ were considered over their full range, from 0 to 1 ; The subject does not have jetties and there is no other restriction on local inletdirected transport from the adjacent beaches, therefore $\mathrm{j}_{1}=\mathrm{j}_{2}=0$. The inlet does not shoal from inland/upland sources, thus $S_{U}=0$. A range of right-directed and left-directed transport rates were applied: $R, L=$ rightward- and leftward-directed incident transport values at the study area's boundaries, $R_{1}=R_{2}=100,000$ to $400,000 \mathrm{cu}$ yd/year; $L_{1}=L_{2}=-100,000$ to $-400,000 \mathrm{cu}$ yd/year.

The equations solved are as follows (Bodge 1999):

$$
\begin{gathered}
\Delta V_{L}=\left(j_{1}+j_{1} m_{1}-m_{1}\right) R_{1}+L_{1}-p_{2} L_{2} \\
\Delta V S H O A L=\left(1-j_{1}-p_{1}+m_{1}-j_{1} m_{1}\right) R_{1}-\left(1-j_{2}-p_{2}+m_{2}-j_{2} m_{2}\right) L \\
\Delta V_{R}=\left(j_{2}+j_{2} m_{2}-m_{2}\right) R_{2}+L_{2}-p_{2} L_{2}
\end{gathered}
$$

Values applied in the 1999-2010 calculation were as follows: Gross volume of sand shoaling within the inlet $=\Delta V_{\text {shoal }}=279,000 \mathrm{cu} \mathrm{yd} /$ year; Volume change rate to the left (north) shoreline $=\Delta V_{L}=$ $-99,000 \mathrm{cu}$ yd/year; Volume change rate to the right (south) shoreline $=\Delta V_{R}=-179,000 \mathrm{cu}$ yd/year.

The Exhaustive Search Method solves equations (1), (2) and (3) iteratively for values of $p_{1}, p_{2}, m_{1}$, $m_{2}, R_{1}, R_{2}, L_{1}$ and $L_{2}$ that fall within the above-specified ranges. The resulting solutions may be plotted by computing net transport, $\mathrm{Q}$, net natural bypassing, $\mathrm{P}$ and gross volume that shoals the inlet from the left and right shorelines, $S_{L}$ and $S_{R}$ respectively. These are defined as follows:

$$
\begin{aligned}
& Q=Q_{1}=R_{1}+L_{1} \\
& Q=Q_{2}=R_{2}+L_{2}
\end{aligned}
$$




$$
\begin{gathered}
P=p_{1} R_{1}+p_{2} L_{2} \\
S_{L}=\left(1-j_{1}-p_{1}+m_{1}-j_{1} m_{1}\right) R_{1} \\
S_{R}=\left(1-j_{2}-p_{2}+m_{2}-j_{2} m_{2}\right) R_{2}
\end{gathered}
$$

An iterative computational routine was coded which solves for all unique values of $\mathrm{Q}, \mathrm{P}, \mathrm{S}_{\mathrm{L}}$ and $\mathrm{S}_{\mathrm{R}}$ that satisfy equations (1), (2) and (3). These results are plotted in Figure 5. The solutions lie along lines of constant net incident sediment transport, Q. The vertical axes are the shoaling of the inlet from left, $\mathrm{S}_{\mathrm{L}}$ and right, $\mathrm{S}_{\mathrm{R}}$. The horizontal axis is the net annual inlet bypassing rate, $\mathrm{P}$, for which negative values (representing net annual bypassing northward) are toward the left and positive values (representing net southward bypassing) are toward the right. The resulting sediment budget Family of Solutions illustrates that shoaling from the right and left shorelines could be anywhere between 0 and 250,000 cu $\mathrm{yd} / \mathrm{yr}$ and net natural bypassing is anywhere from 0 and 450,000 to the left or to the right depending on the direction of net transport, Q.

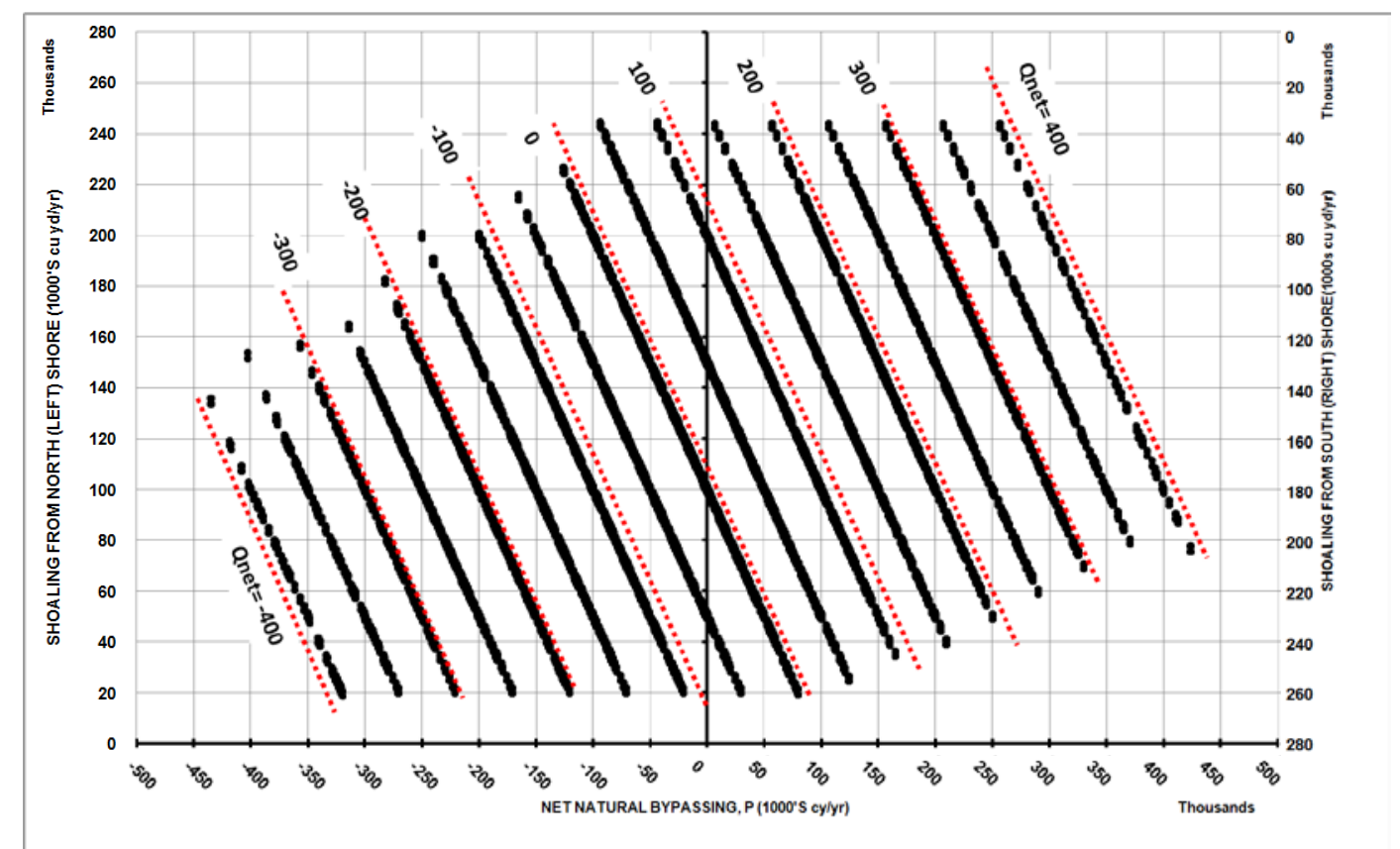

Figure 5: Sediment budget Family of Solutions for St. Augustine Inlet, 1999 to 2010

The family of solutions can be narrowed by imposing addional constraints based on existing literature, new analysis or modeling, observations of historical behavior, etc. For the case of St. Augustine Inlet and its adjacent beaches, the family of solutions was narrowed to those most likely by imposing the following constraints:

1. Net bypassing is southward (positive values of $P$ on the bottom axis in Fig. 5)

2. Shoaling from $S$. Beaches $>33 \%$ of inlet shoaling; $S_{R}>0.3 \Delta V_{\text {shoal }}=93 \mathrm{k} \mathrm{cy} / \mathrm{yr}$

3. Shoaling from Vilano (north) $>$ Shoaling from Anastasia (south); $S_{L}>S_{R}$

4. Bypassing from North $<70 \%$ of net LST; $P<0.7 \mathrm{Q}$

Constraint 1 , net sediment bypassing the inlet is southward, $\mathrm{P}>0$, narrows the solution set to the right half of the family of solutions. Taylor Engineering (1998) and many other sources have concluded that net sediment transport is toward the south within northeastern Florida. In addition, morphologic modeling performed as part of this study (Legault et. al. 2012) also found that net sediment transport is southward. It is assumed that net sediment bypassing the inlet id driven by the net sediment transport direction, which is toward the south, thus $\mathrm{P}>0$. Constraint 2 , further narrows the solution set to those 
that fall below the upper horizontal dashed line, $S_{R}>93 k$ cy/yr. This follows from the assumption that the $179 \mathrm{k} \mathrm{cy} / \mathrm{yr}$ that erode from the south beaches is in large part due to direct shoaling of the south beaches northward into the inlet. Constraint 3 posits that the direct shoaling from the north is greater than direct shoaling from the south. This is supported by the much higher erosion rates for the segment of beach which lies immediately north of the inlet vs. the relatively lower rate of erosion that occurs directly south of the inlet. If $\mathrm{S}_{\mathrm{L}}>\mathrm{S}_{\mathrm{R}}$ this further narrow the solutions to those fall above the lower horizontal line, $\mathrm{S}_{\mathrm{L}}=\mathrm{S}_{\mathrm{R}}=140 \mathrm{k}$ cy/yr. Finally, constraint 4 limits the solutions to those that fall on the left of the diagonal line where $\mathrm{P}<0.7 \mathrm{Q}$. This constraint limits the maximum bypassing to less than $70 \%$ of the net transport; the rate of north beach erosion and inlet shoaling suggest that a substantial volume of sediment that moves toward the inlet is trapped within the inlet.

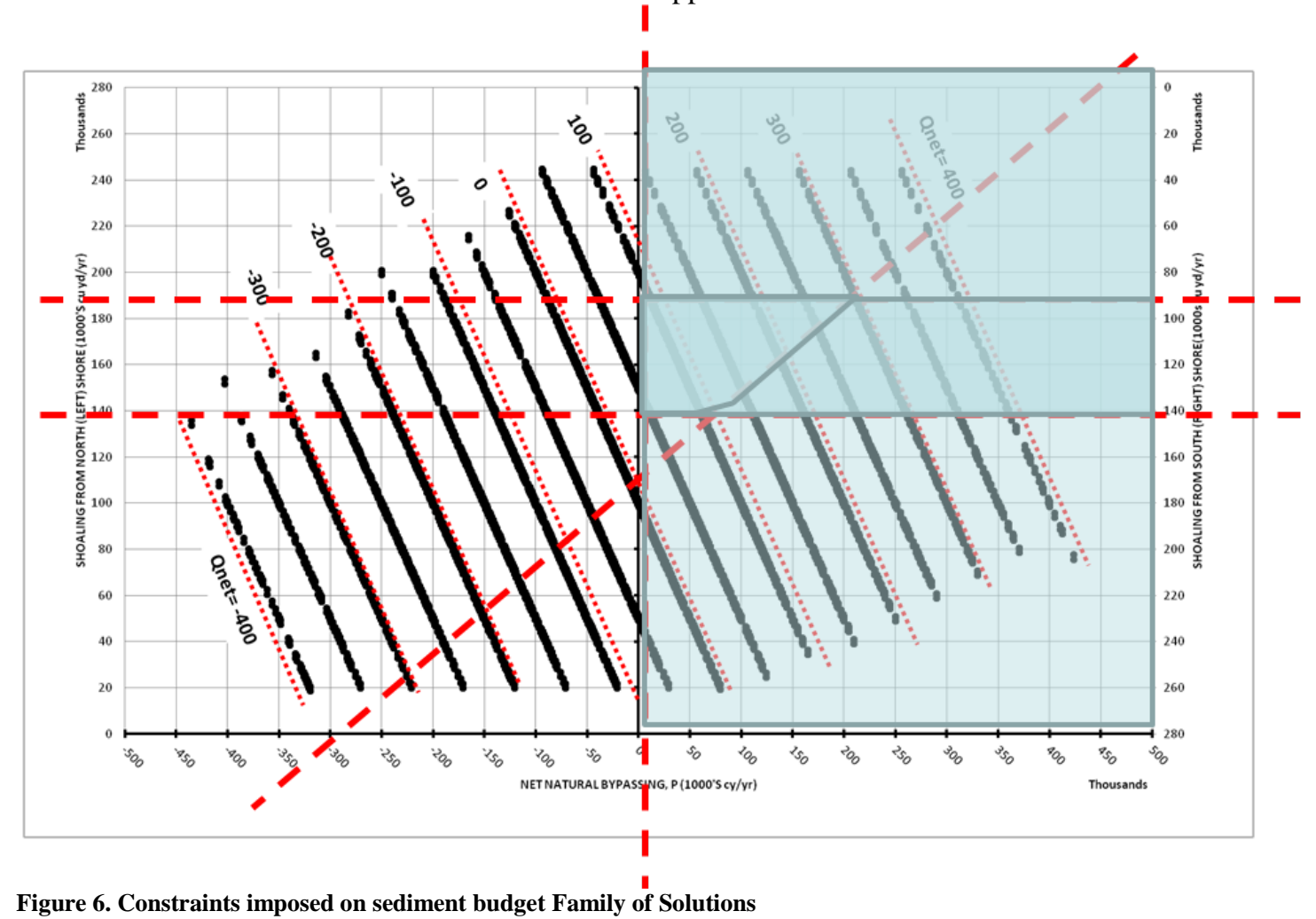

With the solution set constrained two possible unique sediment budget solutions are identified (Fig. 7) based on the geometry of the remaining solution set and the density of solutions that fall within the Family. The modal solution, which is the most frequently-occuring solution, and the centroid of the area represented by all the viable solutions. For each of these solutions, it is important to note that the family of solutions only specifies the net longshore sediment transport rate, Q; these solutions do not completely constrain the gross transport rate at the study boundary. 


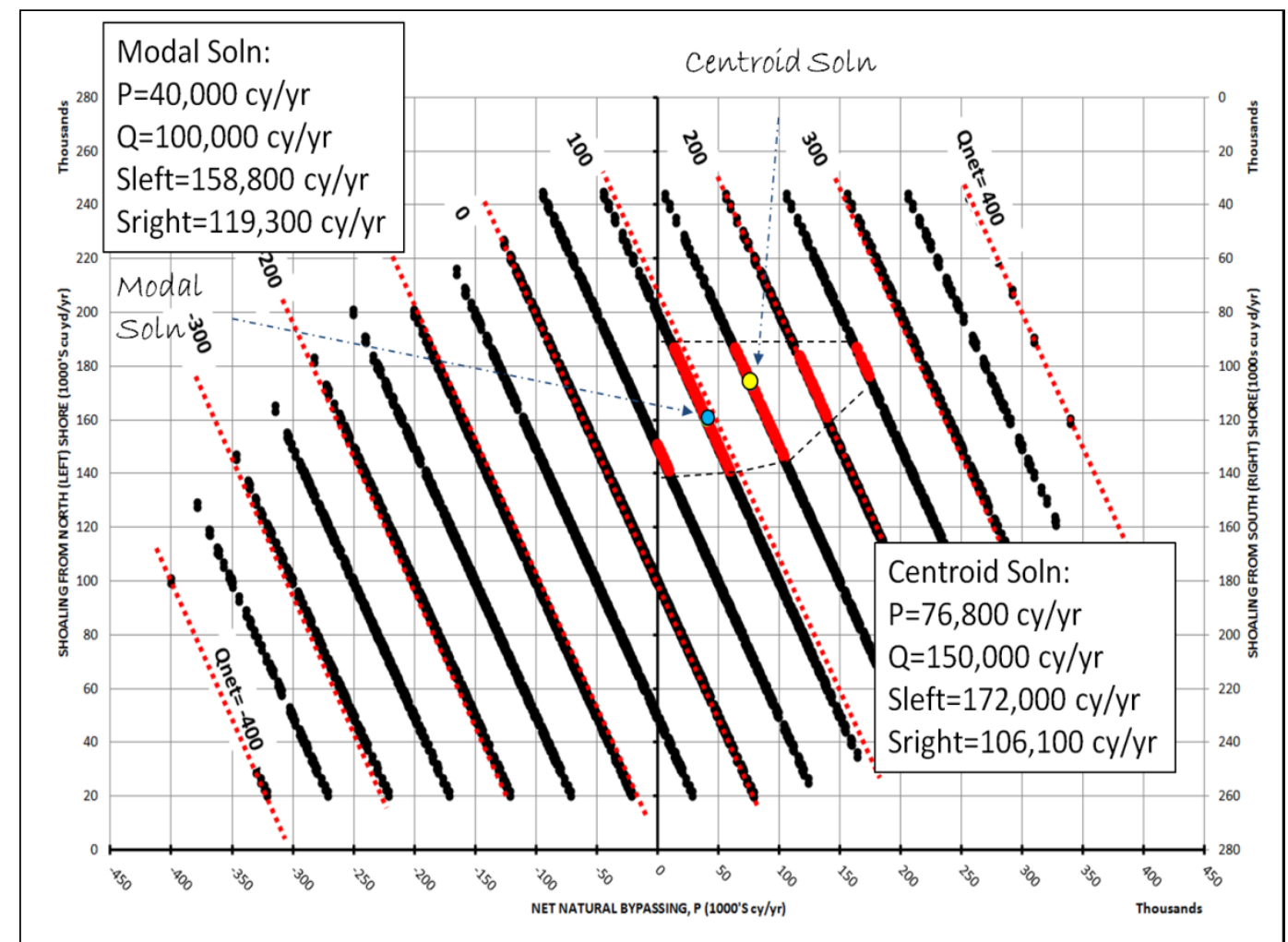

Figure 7. Narrowed Family of Solutions; blue and yellow dots indicate the modal and centroid solutions, respectively, within the Family of Solutions

The centroid solution, shown in Fig. 8, left panel, has a net longshore sand transport at the northern boundary of the study area (R-83) of approximately 150,000 cy/yr, with 77,000 cy/yr bypassing the inlet. Shoaling from the north into the inlet complex was $172,000 \mathrm{cy} / \mathrm{yr}(82,000+90,000)$, and shoaling from the south into the inlet was 106,000 cu yd/year

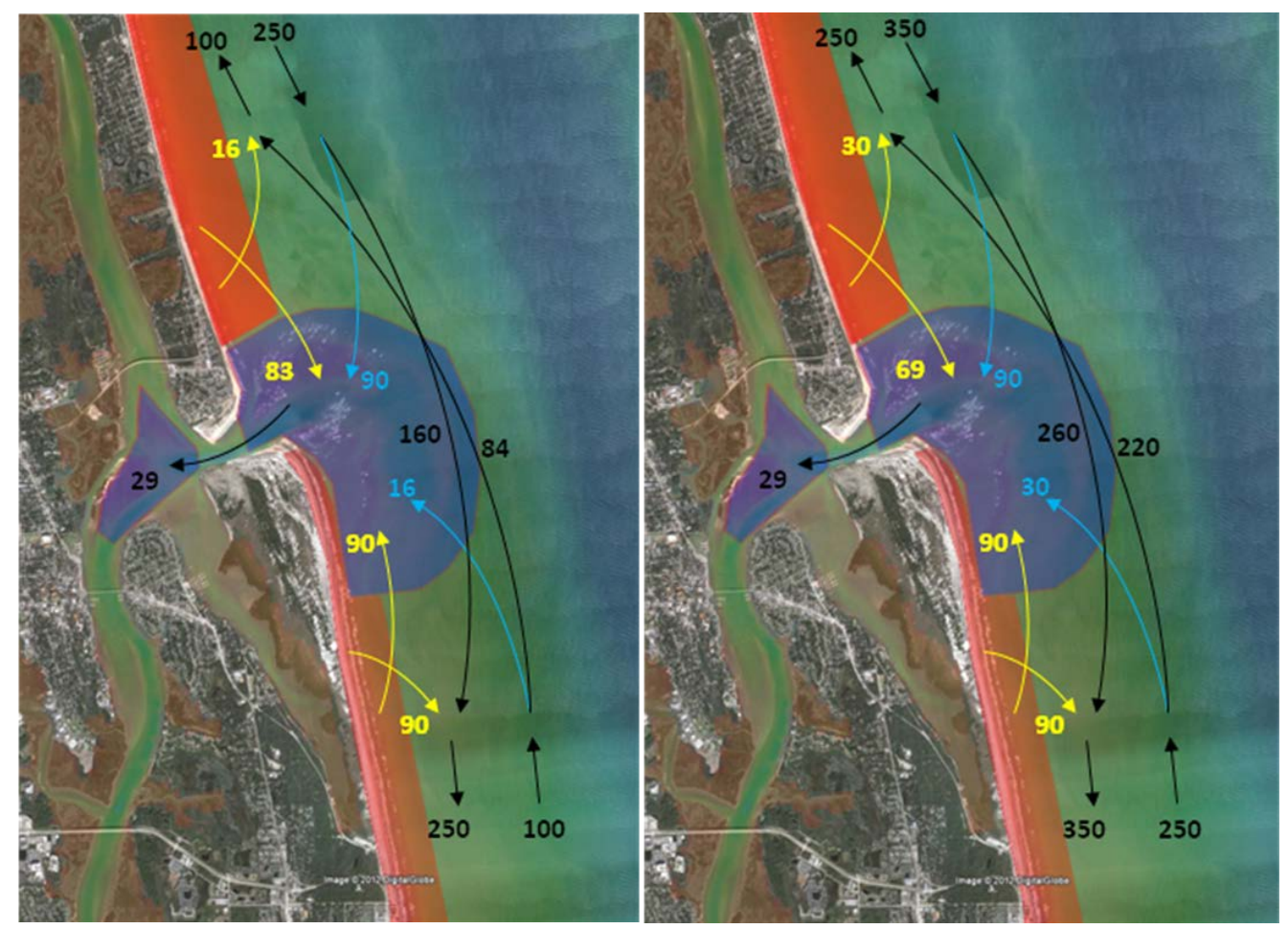

Figure 8: Centroid solution (left panel) and Modal solution (right panel), 1000’s of cy/yr 
$(90,000+16,000 \mathrm{cy} / \mathrm{yr})$. At the southern boundary of the study area (R-151), the net longshore sand transport was to the south, approximately $150,000 \mathrm{cy} / \mathrm{yr}$.

The modal solution, shown in Fig. 8, right panel, indicates a net longshore sand transport entering the study area from the north at R-83 was 100,000 cy/yr, of which 40,000 cy/yr was bypassed and $\sim 159,000 \mathrm{cy} / \mathrm{yr}(69,000+90,000 \mathrm{cy} / \mathrm{yr})$ shoaled into the inlet from the north. Beaches south of the inlet received the net bypassing around the inlet $(40,000 \mathrm{cy} / \mathrm{yr})$ but transported $\sim 120,000 \mathrm{cy} / \mathrm{yr}$ $(90,000+30,000 \mathrm{cy} / \mathrm{yr})$ north to the inlet. At the southern boundary of the study area (R-151), transport was towards the south at approximately 100,000 cy/yr.

\section{DISCUSSION}

The Centroid solution was chosen as the final sediment budget. The sediment budget answers some important questions that were posed by stakeholders prior to this analysis. There has been conjecture that the inlet channel and ebb shoal dredging (as borrow for beach nourishment on the south beaches) had caused the inlet to trap a significant amount of northward transport within the inlet, thereby reducing the sediment supply to the north beaches and causing erosion north of the inlet. The budget indicates that only $16 \%$ of northbound sediment is shoals at the inlet and rest if bypassed to the north beaches. In fact, the north beach loses most of its sand to the inlet via direct shoaling from the north into the inlet. This finding is further supported by the volume change data in Fig. 3, which show that beach erosion north of the inlet was higher prior to the initiation of the large-scale inlet dredging in 2001 than it was after dredging had commenced.

The other issue that was successfully resolved by the updated sediment budget was whether backpassing of inlet sediment to the north beach should be recommended in the next IMP. The existing 1998 IMP does not allow for backpassing, which precludes local stakeholders from renourishing the eroding north beach with sediment from the inlet. The sediment budget clearly shows the direct loss of sand from the north beach into the inlet. The next IMP is expected to allow for backpassing and bypassing, thus removing this restriction. The recommended future actions include backpassing from the inlet ebb and flood shoal complex at a rate of 100,000 cy/yr and bypassing to the south beach at a rate of $180,000 \mathrm{cy} / \mathrm{yr}$.

For a site with known volume change the Exhaustive Search Method is a relatively simple and efficient method for sediment budget development. The solutions are not highly dependent on estimates of LST, which provides flexibility for use on many sites where LST is not well known. In addition, the somewhat subjective process of constraining the Family of Solutions can be used as an opportunity to collaborate with stakeholders so that the resulting sediment budget is acceptable to all parties.

\section{CONCLUSIONS}

A regional sediment budget for St. Augustine Inlet and St. Johns County, Florida, was developed for the 1999 to 2010 period. Development of the sediment budget had three main objectives first, to characterize the transport pathways and magnitudes for the 1999 to 2010 period, next, to determine evaluate the potential for inlet dredging to have negative effects on the adjacent beaches and, finally, to establish sustainable bypassing and backpassing objectives in support of an updated Inlet Management Plan. An innovative method was developed to create an inlet sediment budget using high quality measured volume changes for an inlet and beach system. Methods described in the Coastal Engineering Manual and by Bodge (1999) were applied to determine the extent of inlet influence along the adjacent beaches to establish a new regional sediment budget for a given set of measured volume changes occurring at St. Augustine Inlet in northeast Florida, U.S.A. The centroid solution, shown in Fig. 8, left panel, has a net longshore sand transport at the northern boundary of the study area (R-83) of approximately 150,000 cy/yr, with approximately 77,000 cy/yr bypassing the inlet. Shoaling from the north into the inlet complex was 172,000 cy/yr and shoaling from the south into the inlet was 106,000 $\mathrm{cy} / \mathrm{yr}$. At the southern boundary of the study area (R-151), the net longshore sand transport was to the south, approximately 150,000 cy/yr. This solution was deemed suitable for the development of the new IMP

In summary, St. Augustine Inlet is a valuable sand resource for the beaches of St. Johns County, Florida. If managed properly, the inlet can be dredged at a maximum of 280,000 cu yd/year and will naturally replenish itself without adverse erosion on the adjacent beaches. This rate of mining and placement on the adjacent beaches will partially offset the adjacent beach erosion as observed since 1974 in the region. These analyses, morphologic modeling (Beck and Legault, 2012) as well as monitoring of the adjacent beaches and ebb shoal evolution should continue to ensure the sustainability of future sand management practices at St. Augustine Inlet. 


\section{ACKNOWLEDGMENTS}

This project was partially funded by the National Regional Sediment Management and Coastal Inlets Research Programs of the U.S. Army Corps of Engineers.

\section{REFERENCES}

Beck, T.M. and Legault K.R. 2012(a). St. Augustine Inlet, Florida: Application of the Coastal Modeling System, Report 2. Technical Report ERDC-TR-12-14, U.S. Army Research and Development Center, Vicksburg, MS.

Beck, T.M. and Legault K.R. 2012(b). Optimization of Ebb Shoal Mining and Beach Nourishment at St. Johns County, St. Augustine Inlet, FL., Report 3. Technical Report ERDC-TR-12-14, U.S. Army Research and Development Center, Vicksburg, MS.

Bodge, K.R. 1999. Inlet Impacts and Families of Solutions for Inlet Sediment Budgets. Proc. Coastal Sediments '99, American Society of Civil Engineers, NY, Vol 1, pp. 703-718.

Legault, K., Rosati, J.D., Engle, J.A., and Beck, T.M.. 2012. St. Johns County, St. Augustine Inlet, FL Report 1: Historical Analysis and Sediment Budget. ERDC/CHL-TR-12-14, US Army Engineer Research and Development Center, Coastal and Hydraulics Laboratory, Vicksburg, MS.

Bodge, K.R. and Rosati, J.D. 2003. Chapter 6, Sediment Management at Inlets and Harbors. In: V-6-3 Inlets and Adjacent Beach Sediment Budgets, Engineer Manual 1110-2-1100, U.S. Army Corps of Engineers, Washington, DC. 